\title{
The thermal stability of Eyjafjallajökull ash versus turbine ingestion test sands
}

\author{
Ulrich Kueppers ${ }^{1 *}$, Corrado Cimarelli ${ }^{1}$, Kai-Uwe Hess ${ }^{1}$, Jacopo Taddeucci ${ }^{2}$, Fabian B Wadsworth ${ }^{1}$ \\ and Donald B Dingwell ${ }^{1}$
}

\begin{abstract}
The 2010 eruption of Eyjafjallajökull (Iceland) and the 2011 eruptions of Grimsvötn (Iceland), Cordon Caulle (Chile) and Nabro (Ethiopia) have drastically heightened the level of awareness in the general population of how volcanic activity can affect everyday life by disrupting air travel. The ingestion of airborne volcanic matter into jet turbines may cause harm by (1) abrasion of engine parts, (2) destabilisation of the fuel/air mix and its dynamics and (3) by melting and sintering ash onto engine parts. To investigate the behaviour of volcanic ash upon reheating, we have performed experiments at ten temperature steps between 700 and $1600^{\circ} \mathrm{C}$ on (1) fresh volcanic ash from the final explosive phase of the 2010 Eyjafjallajökull (EYJA) eruption and (2) two standard materials used in ingestion tests in the history of turbine testing (MIL E 5007C test sand, MIL; Arizona Test Dust, ATD). We confirm expected large differences in the samples' response to thermal treatment. We quantify the physical basis for these differences using thermogravimetry and differential scanning calorimetry. Glassy volcanic ash softens at temperatures that are considerably lower than those required for crystalline silicates to start to melt. We find that volcanic ash starts softening at temperatures as low as $600^{\circ} \mathrm{C}$ and that complete sintering takes place at temperatures as low as $1050^{\circ} \mathrm{C}$. Accordingly, the ingestion of volcanic ash in the hot zone of turbines will rather efficiently transform the angular volcanic particles into sticky droplets with a high potential of adhering to surfaces. These experiments demonstrate both a large variability in the material properties of ash from Eyjafjallajökull volcano and a strong contrast to the behaviour of the test sands. In light of these differences, the application in volcanic crises of models of the impact of ash on operability of passenger jet turbines that have been based on test sand calibrations must be re-evaluated. We stress as well that ingestion tests should not only investigate the turbine's response to ash concentration $\left(\mathrm{g} / \mathrm{m}^{3}\right)$ but also to ash dosage.
\end{abstract}

Keywords: Volcanic ash; Glass; Thermal stability; Ingestion tests; Air traffic closure; Volcanic ash detection; Remelting; Sintering

\section{Background}

For many years, the civil aviation authorities have primarily been concerned with localised ash plumes (Guffanti et al. 2010). The year 2010 however marked a dramatic turning point in our perception of associated risks. Beginning with mild explosive activity on the snow-covered eastern flank, the vent position of the Eyjafjallajökull eruption changed to within the glacier-covered summit caldera, causing a marked increase in eruption explosivity (Gudmundsson et al. 2012). The prevailing winds transported the volcanic ash over large areas of the Northern hemisphere

\footnotetext{
* Correspondence: u.kueppers@lmu.de

${ }^{1}$ Earth \& Environmental Sciences, Ludwig-Maximilians-Universität München, Theresienstr. 41, 80333 Munich, Germany

Full list of author information is available at the end of the article
}

and, soon after the eruption onset, caused widespread airport closure in Northern and Central Europe. The dramatic extent of the disruption stemmed from the "zero ash tolerance" guideline followed by decisionmakers at the time of the Eyjafjallajökull eruption. This guideline (Miller and Casadevall 2000; International Civil Aviation Organization [ICAO] 2007) had been implemented by the International Civil Aviation Organization [ICAO] after the 1982 Galunggung (Indonesia) and 1989 Redoubt (USA) incidents (Guffanti et al. 2010; Dunn 2012), based on the Proceedings of the First International Symposium on Volcanic Ash, held in Seattle, Washington, in July 1991 (Casadevall 1994). This rule had been widely accepted by all legal authorities and airline companies, as well as airplane and turbine manufacturers. During the 
Eyjafjallajökull eruption, the combination of eruption duration, meteorological situation and area of airspace closure lead to substantial economic loss, which was not restricted to airline and airport companies (Budd et al. 2011) but also affected industrial activities and goods production.

The increasing duration of airspace closure and the consequent magnitude of economic loss and logistical problems created an increasing reticence towards the imposed flight ban on the part of the airline and cargo companies. However, the rigid implementation of the "zero ash tolerance" guideline undoubtedly avoided hazardous ash encounters. While in-flight ash detection is still a complicated task (Prata and Tupper 2009), airspace contamination by volcanic ash at the time of the Eyjafjallajökull eruption was confirmed for large areas of Europe by direct sampling (Schumann et al. 2011) or LIDAR measurements (Wiegner et al. 2012). At present, the evaluation of the hazard posed by volcanic ash to civil aviation is impeded by 1) the absence of a technology to quantify the ash concentration reliably and quickly at a high temporal and spatial resolution, 2) the invisibility of ash even at concentrations above the currently accepted threshold of $2 \mathrm{mg} / \mathrm{m}^{3}$ (e.g., at night or when overcast; Weinzierl et al. 2012). Recently, the apparent problem of visual detection of volcanic ash (Weinzierl et al. 2012) stimulated a change in terminology and was implemented in the latest ICAO (2013) working paper (IAVWOPSG/7-WP/17).

The "zero ash tolerance" guideline was mainly justified by the limited knowledge about the tolerance of turbine engines to the ingestion of ash particles (Dunn and Wade 1994; Dunn 2012). However, for other types of particulate matter more commonly ingested (e.g., mineral sand) flight operations are permitted within a certain threshold of particle concentration. Under pressure from media and airline companies, turbine manufacturers were asked for a concentration threshold below which safe flying conditions in volcanic ash could be declared possible. This threshold value, currently replacing the "zero ash tolerance" limit, is set at $2 \mathrm{mg} / \mathrm{m}^{3}$ (at the time of writing; e.g., Emmott 2010) and has been empirically chosen to fall between known safe flying conditions in mineral sand (data from military jet turbines, e.g., Gabbard et al. 1982) and what are considered 'dangerous' ash concentrations, estimated by reference to ash deposition within turbines during the 1982 and 1989 incidents (the value of ash concentration responsible for the Galungung accident was however largely overestimated; pers. comm. W. Aspinall). A more quantitative assessment of the hazard posed by ash ingestion into turbine engines is highly desirable.

The response of turbine engines to the ingestion of different types of particulate matter will strongly depend on their chemical and physical characteristics, especially at high temperature. Particles suspended in the atmosphere may have very different origins, including volcanic ash, aeolian sand or incineration residues, and thus different chemical and physical characteristics. Particle shape imposes a strong effect on the viscous sintering rates in so far as sintering timescales are dependent on curvature of the surface in contact with the substrate in a jet engine. Therefore, a particle with a high aspect ratio, which impacts the jet engine surface end-on, will sinter at a faster rate than a spherical particle of the same volume because the contact curvature is higher than the spherical equivalent. It arises from sintering theory that particle roughness likely plays a role, albeit a less important one. The chemical composition of rocks is usually declared as a list of elements expressed as oxides. With the exception of natrocarbonatitic melts that also may erupt explosively (Keller et al. 2010), the major constituent in volcanic rocks is silica, $\mathrm{SiO}_{2}$. The $\mathrm{SiO}_{2}$ content, however, may reflect the contributions of many silicate phases other than quartz crystals. Furthermore, due to high cooling or degassing rates during eruption, volcanic ash usually contains a fraction of silicate glass, i.e., an amorphous phase lacking long-range crystallographic order. Glass and crystals behave very differently during heating. Glass may soften and melt, deform and stick to surfaces, at temperatures as low as $700^{\circ} \mathrm{C}$. Deposition inside turbines will change the internal aerodynamic conditions, affect the temperature of individual components (e.g., by clogging cooling holes), and may react chemically with the thermal-barrier coating. In order to sustain the high temperatures necessary for increased efficiency, parts within the hot zone of the turbine rely on thermal-barrier coatings to operate at temperatures in excess of the melting point of the underlying alloys. Crystalline silicates, in contrast, typically exhibit melting temperatures far higher than the glass softening temperature; crystalline $\mathrm{SiO}_{2}$, for example, has a melting point above $1700^{\circ} \mathrm{C}$. Accordingly, the effect of ash on the operational reliability of aircraft turbines is expected to be very different from that of any mineral sand dominated by quartz.

Sintering of glass, crystals and multi-phase mixtures is a relatively well-understood process in ceramics (Scherer 1977; Scherer and Bachman 1977), physics (Frenkel 1945) and volcanology literature (Sparks et al. 1999). Sintering begins with the formation of necks between particles and involves the transition of a dominantly granular material to a porous framework (Scherer 1977). This initial stage sintering or sticking occurs by viscous neck formation in supercooled melts (high temperature equivalent of glass) and by diffusive neck formation in crystalline material (Frenkel 1945). For a given temperature, the latter is generally a slower process but depends strongly on the crystal composition and thermal stability (Zarzycki 1991; Uhlmann et al. 1975). However, in the simpler glass/melt system, is generally accepted that sintering timescales $(\tau)$ 
are dependent on initial grain size $(R)$, melt viscosity $(\eta)$ and melt surface tension $(\gamma)$; given by (Uhlmann et al. 1975):

$$
\tau=\frac{R \eta}{\gamma}
$$

In our experiments with natural volcanic ash, for a constant grain size and composition, the sintering timescale is therefore entirely governed by viscosity and therefore time and temperature dependent. However at the same temperature conditions, the grain size of ingested ash particles should play a critical role in the timescale of effective sintering and therefore grain size will be the prime parameter controlling the probability that particles colliding with each other or with surfaces will adhere and accumulate in engines (Vasseur et al. 2013). Substrate materials in jet engines are not well publicised and therefore the sintering behaviour of particles on a particular substrate remains unconstrained. There is remarkably little literature on sintering as a function of substrate material. This is especially true when considering a single particle and not a granular mixture. However, there is prodigious literature showing and modelling how this can happen in, for example, coal combustion devices with metal substrates (Tomeczek et al. 2004; Song et al. 2009). For this reason we consider the sintering of particles to other particles of the same material as an approximate proxy to the timescales and characteristics of sintering to a metal substrate or to a thermal barrier coating. We concede that further research in this area is necessary. For the theoretical model (Eq. 1), a spherical particle shape is assumed. Figure 1 clearly shows that none of the three samples is comprised of particles of this shape. The shape of the particles will affect the sintering timescale, as heat conductivity is surface area controlled. The effect of grain shape on sintering timescale was not the target of this study.

Several working groups have characterized Eyjafjallajökull ash (Bonadonna et al. 2011; Dellino et al. 2012; Taddeucci et al. 2011). Further, reaction with metallic surfaces was investigated for natural ash (Gislason et al. 2011) and chemically comparable analogue materials (Mechnich et al. 2011) by constraining "size, shape, and hardness [...] as well as the chemical composition of the salt condensates on the particle surfaces" of ash that was sampled dry. To the best of our knowledge, no investigation has compared the response of Eyjafjallajökull ash and mineral sands to reheating.

In this study, we compare the ash collected during the Eyjafjallajökull eruption (EYJA) to two different test sands commonly employed as turbine contaminants; the "Arizona Test Dust" (ATD) and the "MIL E 5007C" test sands (MIL). We focus on the response of static powder samples to heating for 30,60 or 120 minutes, respectively, at 1 bar pressure.

\section{Sample characterisation Eyjafjallajökull ash}

The ash sample E4 (EYJA) was collected on 18 May 2010 along the plume dispersal axis at $7.5 \mathrm{~km}$ north from the vent as it sedimented from the ash cloud. The sample's grain size distribution is smaller than $1 \mathrm{~mm}$ and displays a positive skewness (modal value at $500 \mu \mathrm{m}$ ) with a secondary peak at $63 \mu \mathrm{m}$. This bimodal distribution can be attributed to the process of aggregation by finer particles $(<125 \mu \mathrm{m})$ acting at the time of sampling, enabling the premature depletion of the finer grains from the ash cloud (Taddeucci et al. 2011). Under Field-Emission Scanning Electron Microscope (FE-SEM) the sample appears almost entirely composed of juvenile material, ranging in vesiculation from highly vesicular (Figure 1a) to non-vesicular. Clasts are mostly glassy with variable contents of microlites (crystals smaller than $10 \mu \mathrm{m}$, mostly plagioclase, clinopyroxene and oxides, Figure 1b). Chemical bulk composition has been determined by X-Ray Fluorescence (XRF) analysis, while single-spot composition of the glass matrix has been determined by Electron Microprobe Analysis (EMPA, Table 1). Higher values of $\mathrm{SiO}_{2}$ within the glassy matrix with respect to the bulk composition are consistent with the presence of crystals in the groundmass and, although rare, of loose crystals in the whole sample (Taddeucci et al. 2011).

\section{Arizona test dust}

The characteristics of the Arizona Test Dust (ATD) follow the specification of the International Organization for Standardization ISO 12103-1 "Road Vehicles - Test Dust for Filter Evaluation". The ATD is used as a test contaminant for fuel system components, water filter performance evaluation and other custom applications. It consists of a granular material of mixed silicate mineralogy with grain size smaller than $200 \mu \mathrm{m}$ (Figure 1c). We purchased two different grades of ATD from Powder Technology Inc., ATD-A2 fine grade $(<120 \mu \mathrm{m})$ and ATD-A4 coarse grade $(<200 \mu \mathrm{m})$, respectively. Grains from both samples are texturally homogeneous, dense and display angular shapes. Chemical compositions of the bulk samples and average composition of single grains have been determined from XRF and EMPA analyses respectively, and are reported in Table 1. Since ATD is mainly employed for the testing of particulate filters, the manufacturer has no criteria for strict controls on its bulk composition and reports the range of compositions for different ATD grades (expressed in wt\% of oxides) as follows: $\mathrm{SiO}_{2}$ 68.0-76.0; $\mathrm{CaO}$ 2.0-5.0; $\mathrm{Al}_{2} \mathrm{O}_{3}$ 10.0-15.0; $\mathrm{MgO}$ 1.0-2.0; $\mathrm{Fe}_{2} \mathrm{O}_{3}$ 2.0-5.0; $\mathrm{TiO}_{2}$ 0.5-1.0; $\mathrm{Na}_{2} \mathrm{O}$ 2.0-4.0; $\mathrm{K}_{2} \mathrm{O}$ 2.0-5.0. XRF analyses of the 

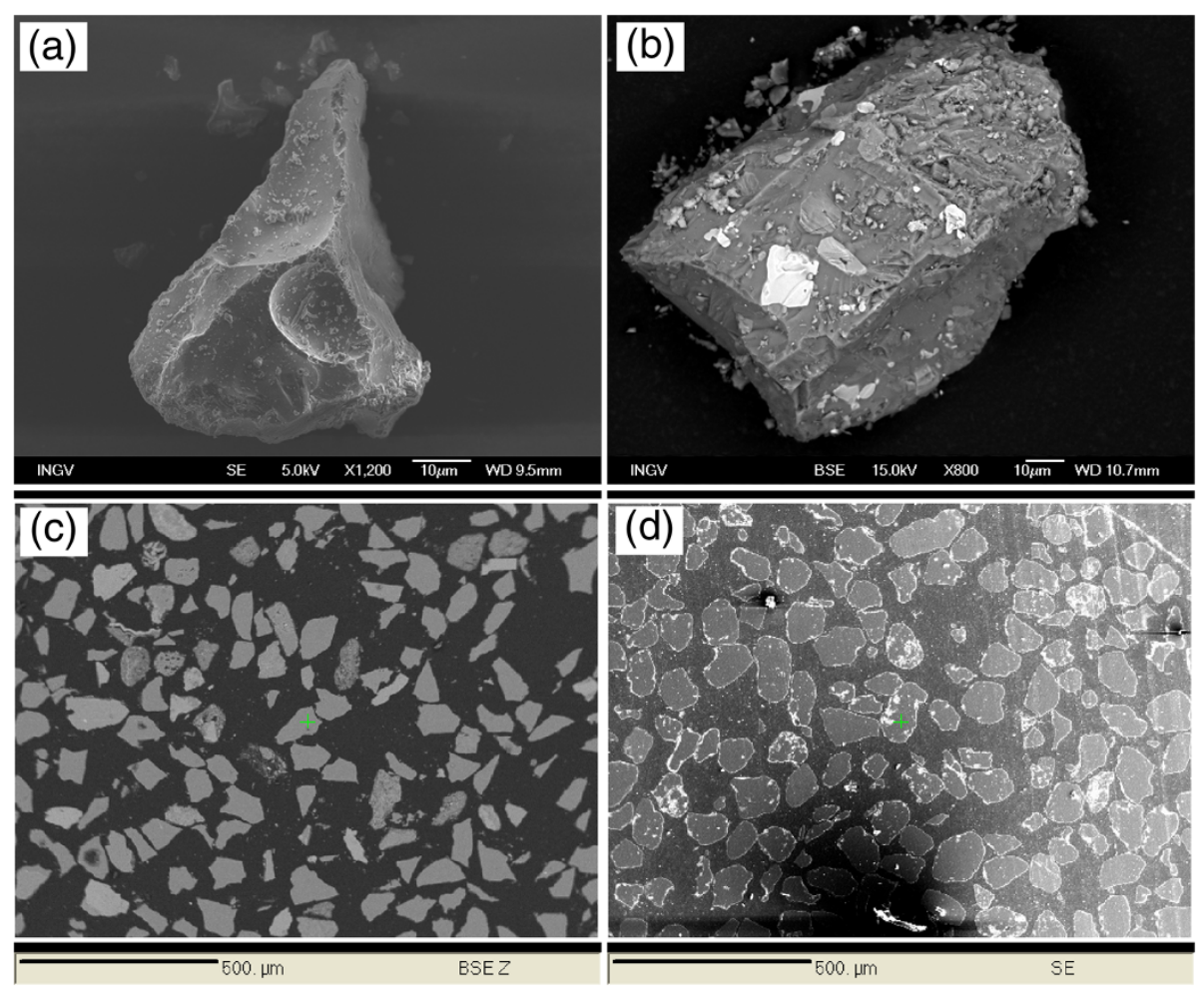

Figure 1 SEM images of single and embedded grains. a) and b) showing different EYJA grains showing the porous nature (a) and the microlite content (b); c) shows the angular shape of ATD grains; $\mathbf{d}$ ) shows the rounded shape of MIL grains.

bulk sample (Table 1) show that the ATD-A2 composition is in good agreement with the composition given by the manufacturer, while ATD-A4 composition is slightly different, being dominated by $\mathrm{SiO}_{2}$ with minor wt\% of $\mathrm{Al}_{2} \mathrm{O}_{3}, \mathrm{FeO}, \mathrm{CaO}, \mathrm{Na}_{2} \mathrm{O}, \mathrm{K}_{2} \mathrm{O}$.
MIL E $5007 C$

The characteristics of the sample MIL E 5007C (MIL) follow the specification of the USA Department of Defence standards (also called Military Standard; MILSTD) for engine, aircraft, turbojet and turbofan. In good

Table 1 Representative EPMA and XRD results of the EYJA, ATD and MIL samples used in this study

\begin{tabular}{|c|c|c|c|c|c|c|c|c|c|}
\hline & & & EPMA point ana & ysis & & & XRD bulk & ock composition & \\
\hline & $A$ & C & D & $E$ & $F$ & $A$ & C & $E$ & $F$ \\
\hline & EYJA & MIL & MIL & ATD & ATD & EYJA & MIL & ATD & ATD \\
\hline & $\varphi<63 \mu \mathrm{m}$ & $\varphi<63 \mu \mathrm{m}$ & $90<\varphi<125 \mu \mathrm{m}$ & $90<\varphi<125 \mu \mathrm{m}$ & $\varphi<63 \mu \mathrm{m}$ & $\varphi<63 \mu \mathrm{m}$ & $\varphi<63 \mu \mathrm{m}$ & $90<\varphi<125 \mu \mathrm{m}$ & $\varphi<63 \mu \mathrm{m}$ \\
\hline $\mathrm{SiO}_{2}$ & 66.38 & 100.48 & 100.35 & 100.13 & 100.14 & 60.72 & 95.92 & 88.34 & 74.02 \\
\hline $\mathrm{Al}_{2} \mathrm{O}_{3}$ & 15.62 & 0.03 & 0.06 & 0.02 & 0.02 & 14.82 & 2.97 & 5.67 & 10.79 \\
\hline $\mathrm{FeO}$ & 4.81 & 0.01 & 0.03 & 0.02 & 0.07 & 8.99 & 0.46 & 0.92 & 2.97 \\
\hline $\mathrm{MnO}$ & 0.16 & 0.00 & 0.00 & 0.00 & 0.00 & 0.21 & 0.00 & 0.03 & 0.09 \\
\hline $\mathrm{MgO}$ & 0.62 & 0.00 & 0.00 & 0.01 & 0.00 & 2.51 & 0.15 & 0.47 & 1.33 \\
\hline $\mathrm{CaO}$ & 2.78 & 0.03 & 0.01 & 0.02 & 0.02 & 4.58 & 0.04 & 1.25 & 2.49 \\
\hline $\mathrm{Na}_{2} \mathrm{O}$ & 5.26 & 0.01 & 0.01 & 0.00 & 0.01 & 5.81 & 0.22 & 1.03 & 1.32 \\
\hline $\mathrm{K}_{2} \mathrm{O}$ & 2.61 & 0.01 & 0.01 & 0.01 & 0.00 & 2.27 & 1.59 & 1.78 & 2.65 \\
\hline $\mathrm{TiO}_{2}$ & 0.70 & 0.01 & 0.00 & 0.00 & 0.00 & 1.39 & 0.13 & 0.12 & 0.38 \\
\hline $\mathrm{P}_{2} \mathrm{O}_{5}$ & 0.18 & 0.00 & 0.00 & 0.00 & 0.01 & 0.25 & 0.03 & 0.05 & 0.13 \\
\hline $\mathrm{Cl}$ & 0.22 & 0.00 & 0.00 & 0.01 & 0.00 & & No & analysed & \\
\hline Total & 99.34 & 100.58 & 100.47 & 100.22 & 100.27 & 101.55 & 101.51 & 99.66 & 96.17 \\
\hline
\end{tabular}

Sample labeling, measured values and cumulative results in bold for clarification. 
commercial quality, it consists of crushed quartz finer than $1 \mathrm{~mm}$. For our experiments, we sieved the bulk sample to obtain two sub-samples, $90<\phi<125 \mu \mathrm{m}$ (Figure 1d) and $\phi<63 \mu \mathrm{m}$. BSE images reveal a better rounding of most MIL grains in respect to ATD. Chemical analyses of single grains and bulk sample (Table 1) are in good agreement and confirm the homogeneous mineralogical composition (almost entirely pure quartz) of the samples.

\section{Methods}

\section{Thermal treatment}

Sintering is the process of sticking and cohesion of initially granular particles as a function of heating rate, temperature, composition and grainsize. Sintering is the adherence of particles by diffusive or viscous remobilisation of material to form necks, joining particles in contact with one another. In this study we assess the grainsizeand temperature-dependence of sintering times. We performed 25 experiments with 133 sample specimens at ten temperature steps between 700 and $1600^{\circ} \mathrm{C}$ and ambient atmosphere. We started with $0.3 \mathrm{~g}$ of new material placed in a Calcium Phosphate-crucible (i.e. static experiments). We observed some limited chemical and mechanical interaction between sample and crucible. Chemical interactions are not a focus of the current study; however, the mechanical interaction, the flowing of molten sample into the crucible's pore space, was clearly correlated with the experimental temperature and was constrained qualitatively. Irrespective of their differing chemical compositions, porosity within the crucibles used in this study is also a property exhibited by thermal barrier coatings (see Figures eight and nine in Mechnich et al. 2011). For each sample (EYJA, ATD and MIL) we used two different grain sizes: $\phi<63 \mu \mathrm{m}$ and $90<\phi<125 \mu \mathrm{m}$. Sets of 18 samples have been placed in the furnace at the experimental temperature, removed after 30, 60 or 120 minutes, respectively, and allowed to cool under ambient conditions. After cooling, we qualitatively assessed macroscopic changes by classifying the samples in one of the following classes: granular (unsintered powder), partially sintered (individual particles adhere at points of contact and neck formation), efficiently sintered and texturally completely densified. Selected samples were embedded in epoxy, cut and polished to allow thin section and SEM analysis.

\section{Thermal stability}

A series of three different measurements have been performed to quantitatively constrain the sample responses to heating.

1. Thermogravimetric (TG) measurements were carried out using a Netzsch STA 449 C thermal balance. Sample powder of approx. $30 \mathrm{mg}$ was heated in a platinum crucible (with lid) at a heating rate of $10 \mathrm{~K} / \mathrm{min}$ to $1500^{\circ} \mathrm{C}$ in an argon atmosphere.

2. Calorimetric (differential scanning calorimetry, DSC) measurements have been performed using a high temperature, low sensitivity Netzsch STA 449C. Approx. $30 \mathrm{mg}$ were heated in a platinum crucible with a heating rate of $10 \mathrm{~K} / \mathrm{min}$ to $1325^{\circ} \mathrm{C}$.

3. Calorimetric (differential scanning calorimetry, DSC) measurements have been performed using a low temperature, high sensitivity Setaram Sensys Evo. Approximately $60 \mathrm{mg}$ were heated in a platinum crucible with a heating rate of $10 \mathrm{~K} / \mathrm{min}$ to $800^{\circ} \mathrm{C}$ in an argon atmosphere. This measurement was performed only on EYJA samples.

\section{Results}

1. The major element composition (Table 1) was quantified as single point (microprobe) and bulk rock (XRF) analyses (see Appendix for details of analytical conditions). FE-SEM images reveal a variable microlite content for EYJA (Figure 1a,b) while ATD (Figure 1c) and MIL (Figure 1d) are almost exclusively composed of quartz grains. In the ATD sample, we observe that the quartz grains are coated with another mineral phase, most likely clay (see DSC results). The differences between the two chemical data sets are minor for MIL, moderate for EYJA and high for ATD. We observe a generally angular shape for clasts of EYJA and ATD while most clasts of MIL are subrounded to rounded. EYJA clasts show abundant segments of bubble walls from broken bubbles. The EYJA ash was found to be strongly degassed with measured water contents below $0.1 \mathrm{wt} . \%$.

2. Sintering experiments: samples were held in the furnace for 30, 60 or 120 minutes, respectively, and allowed to cool under ambient conditions (Figure 2a). Most samples changed colour due to oxidizing conditions within the furnace. The samples were investigated for particle-particle cohesion by using a needle to test the possibility of low-force indentation. We defined three categories; loose, sintered and homogenised. We find that the starting grain size has a minor influence during experiments on EYJA samples and that macroscopically detectable sintering starts consistently between 850 and $900^{\circ} \mathrm{C}$ (Figure 2b). At higher temperatures (Figure 2c), finer samples show a more complete densification. During experiments with crystalline sands, the influence of the grain size is more noticeable and sintering was found to occur at $1100^{\circ} \mathrm{C}$ (Figure 2c) for fine ATD and $1200^{\circ} \mathrm{C}$ for coarse ATD. We observed complete homogenisation at $1050^{\circ} \mathrm{C}$ for the volcanic ash; at $1200^{\circ} \mathrm{C}$ (Figure 2d) for the fine ATD; and at $1400^{\circ} \mathrm{C}$ 

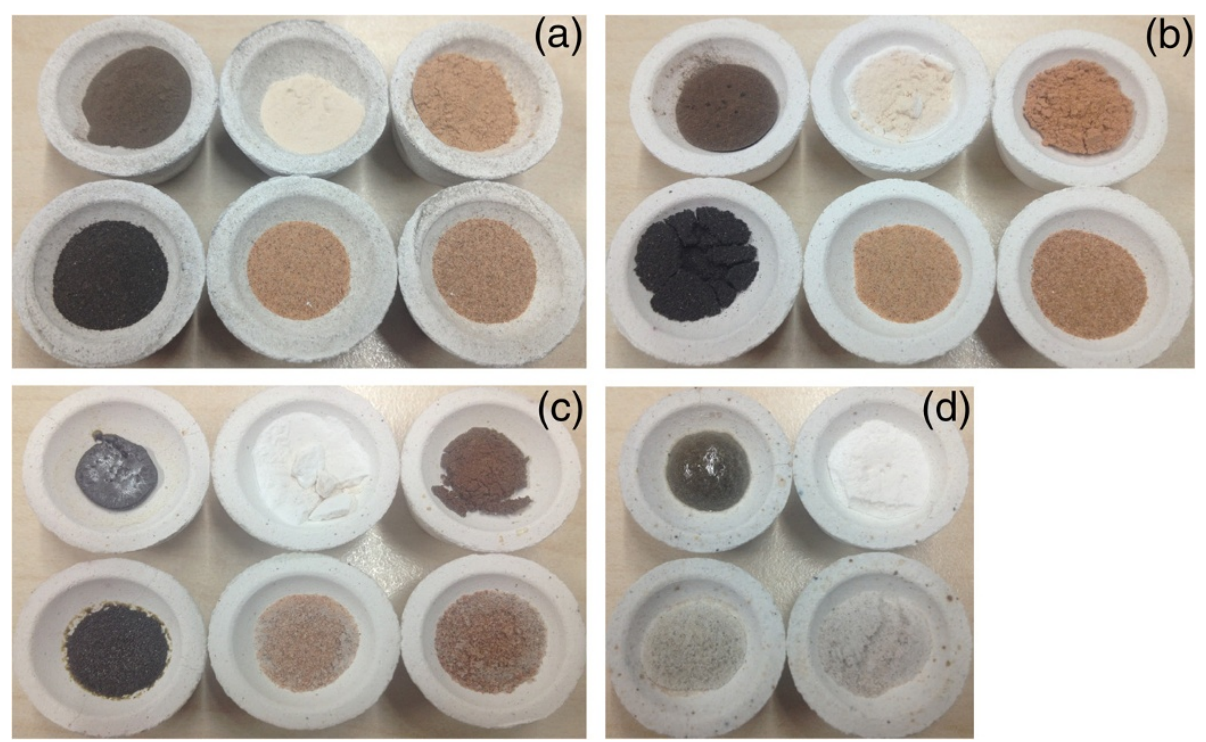

Figure 2 Photos of the samples (a) after $60 \mathrm{~min}$ at $700^{\circ} \mathrm{C}$ (no observable change), (b) after $60 \mathrm{~min}$ at $900^{\circ} \mathrm{C},(\mathrm{c})$ after $60 \mathrm{~min}$ at $1100^{\circ} \mathrm{C}$ and (d) after $60 \mathrm{~min}$ at $1200^{\circ} \mathrm{C}$ (each crucible has a diameter of $22 \mathrm{~mm}$ ). Arrangement of samples in (a) through (c): top row from left to right: EYJA, ATD and MIL (all $\varphi<63 \mu \mathrm{m}$ ); bottom row from left to right: EYJA, ATD and MIL (all $90<\varphi<125 \mu \mathrm{m}$ ). Arrangement of samples in (d): top row from left to right: ATD and MIL (all $\varphi<63 \mu \mathrm{m}$ ); bottom row from left to right: ATD and MIL (all $90<\varphi<125 \mu \mathrm{m}$ ). After 60 minutes at $700^{\circ} \mathrm{C}$ (a), all samples are still loose powders. After 60 minutes at $900^{\circ} \mathrm{C}(\mathbf{b})$, EYJA samples show signs of sintering (crusted surface), all other samples are still loose powders. After 60 minutes at $1100^{\circ} \mathrm{C}$ (c), EYJA samples are completely sintered whereas all other samples are still loose. After 60 minutes at $1200^{\circ} \mathrm{C}$ (d), ATD is partially sintered $(90<\varphi<125 \mu \mathrm{m})$ and completely welded $(\varphi<63 \mu \mathrm{m})$, respectively, whereas MIL samples are still loose powders.

for the coarse ATD. The MIL sample shows signs of a homogenisation onset at $1400^{\circ} \mathrm{C}$ (Table 2).

3. Infiltration of substrate: Above $850^{\circ} \mathrm{C}$, all volcanic ash samples show signs of sintering, the extent of which correlated positively with experimental temperature. Samples from three experiments $\left(60 \mathrm{~min}\right.$ at $\mathrm{T}_{\exp }=950,1000$ and $\left.1050^{\circ} \mathrm{C}\right)$ were impregnated and sectioned vertically to expose the reaction rim between sample and sample holder. This analysis mainly aims at understanding the physics of the process and not the inevitable chemical reactions occurring between the parts of the sample in contact with the crucible. We observed the strong influence of viscosity on the infiltration of silicate melt into the porous structure of the used crucibles. At $950^{\circ} \mathrm{C}$, no significant melting is obvious (Figure 3a), best evidenced at higher resolution through the newly-formed glass necks (Figure $3 \mathrm{~b}$ ). At $1000^{\circ} \mathrm{C}$, the glass necks become more numerous and thicker (Figure 3c) but only the basal ash grains show efficient loss of interparticle porosity by viscous flow (Figure $3 \mathrm{~d}$ ). At $1050^{\circ} \mathrm{C}$, all ash particles have formed a coherent and dense mass (Figure 3e) that was low enough in viscosity to infiltrate the sample holder (Figure 3f).

4. TG: The thermogravimetric measurements revealed (independent of grainsize) no mass loss for EYJA and MIL in the temperature interval between room temperature and $1325^{\circ} \mathrm{C}$ (experimental error $+/-$ 0.1 wt.\%). In contrast, ATD reveals a significant

Table 2 Qualitative results of the degree of sintering of the EYJA, MIL and ATD samples

\begin{tabular}{|c|c|c|c|c|c|c|c|c|c|c|c|c|}
\hline & \multicolumn{12}{|c|}{ Experimental temperature $\left({ }^{\circ} \mathrm{C}\right)$} \\
\hline & & 700 & 800 & 850 & 900 & 950 & 1000 & 1050 & 1100 & 1200 & 1400 & 1600 \\
\hline \multirow[t]{6}{*}{ Sample } & EYJA $(\Phi<63 \mu \mathrm{m})$ & No & No & Onset & Yes & Yes & Yes & Texturally densified & n.p. & n.p. & n.p. & n.p. \\
\hline & EYJA $(90 \mu \mathrm{m}<\Phi<125 \mu \mathrm{m})$ & No & No & Onset & Yes & Yes & Yes & Texturally densified & n.p. & n.p. & n.p. & n.p. \\
\hline & MIL $(\Phi<63 \mu \mathrm{m})$ & No & No & No & No & No & No & No & No & No & Onset & Yes \\
\hline & MIL $(90 \mu \mathrm{m}<\Phi<125 \mu \mathrm{m})$ & No & No & No & No & No & No & No & No & No & Onset & Yes \\
\hline & ATD $(\Phi<63 \mu \mathrm{m})$ & No & No & No & No & No & No & No & Onset & Yes & Texturally densified & n.p. \\
\hline & ATD $(90 \mu \mathrm{m}<\Phi<125 \mu \mathrm{m})$ & No & No & No & No & No & No & No & No & Onset & Yes & n.p. \\
\hline
\end{tabular}



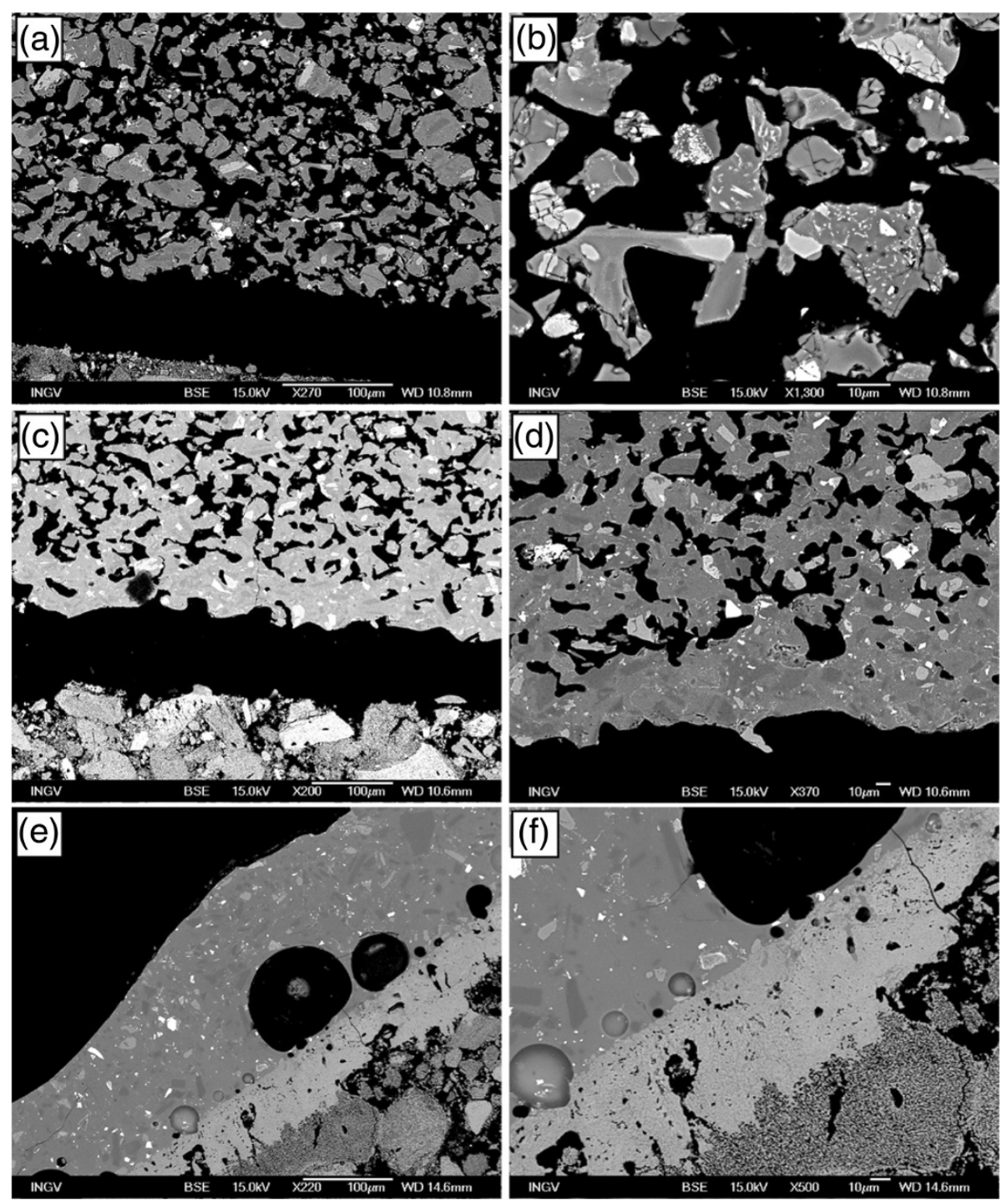

Figure 3 SEM images of impregnated thin section showing the different degrees of sintering from quasi-initial conditions after 60 minutes at $950^{\circ} \mathrm{C}$ (a overview, b detail), through considerable neck formation after 60 minutes at $1000^{\circ} \mathrm{C}$ (c overview, d detail) to complete textural densification after 60 minutes at $1050^{\circ} \mathrm{C}$ (e overview, $\mathrm{f}$ detail).

mass loss of up to 3 wt.\% between room temperature and $700^{\circ} \mathrm{C}$ (Figure 4).

5. The heat flow signal measured by high-T DSC across a heating interval up to $1325^{\circ} \mathrm{C}$ shows a fundamental difference between EYJA (black line) and the other samples (Figure 5); the latter two showing a unique peak at $573+/-2^{\circ} \mathrm{C}$ ( $\alpha$ to $\beta$-quartz transition).

6. The glass transition interval was measured for EYJA by low-T DSC and revealed a broad, endothermic peak starting at $600^{\circ} \mathrm{C}$ (Figure 6). Remelted ash from the TG measurements shows are more pronounced peak, also starting at $600^{\circ} \mathrm{C}$. Here, the glass structure starts to relax, manifested in a measurable change in sample length (Figure 4). We did not observe a comparable response of MIL or ATD.

\section{Discussion and conclusions}

Constraining the impact of volcanic ash on the operational reliability of passenger turbines is difficult because many important parameters are highly variable due to natural and/or engineering reasons: 1) Volcanic ash composition, 2) glass fraction (Kennedy and Russell 2012), 3) interstitial melt/bulk rock composition, 4) ash concentration, 5) grainsize distribution at turbine inlet, 6) air flow speed inside a turbine, 7) temperature inside a turbine, 8) maximum pressure inside a turbine, 9) degree of grainsize reduction inside the turbine and 10) dominant grainsize in the hot zone of the turbine.

In May 2010, a bubbly magma (Figure 1a) with some crystalline content was erupted at Eyjafjallajökull. The widespread ash affected aviation significantly as modelled 


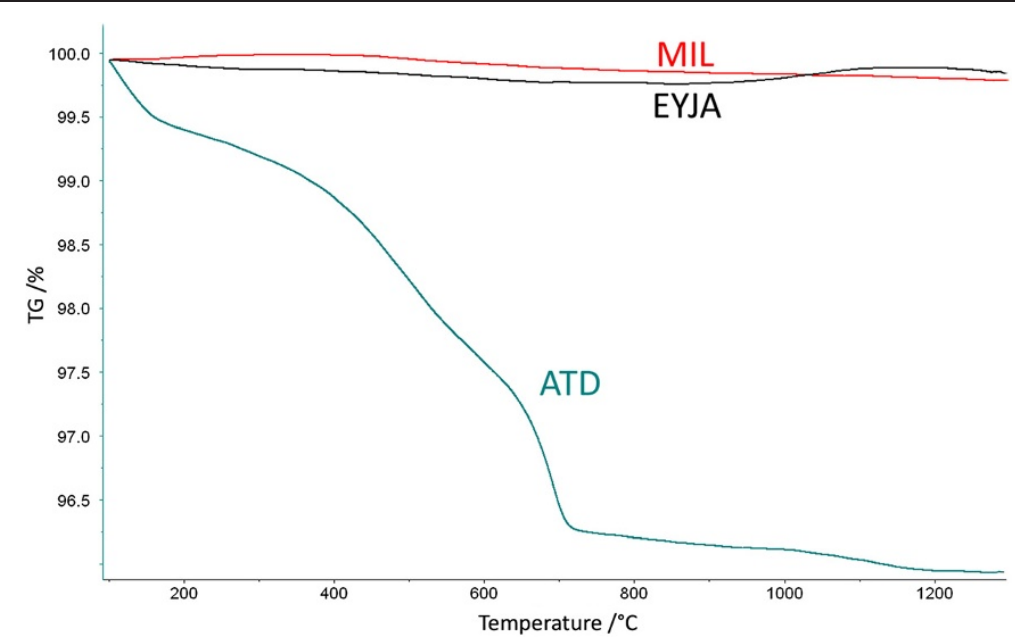

Figure 4 Results of thermogravimetry analysis (Pt crucibles were used at $10 \mathrm{~K} / \mathrm{min}$ heating rate under argon atmosphere.) for the $90<\varphi<125 \mu \mathrm{m}$ grainsize fraction. EYJA and MIL samples show a fairly similar behaviour whereas ATD shows a significant weight loss (4 wt.\%) that can be attributed to decomposition reactions, most likely of $\mathrm{H}_{2} \mathrm{O}$-bearing phases.

results predicted ash over large areas of northern and central Europe. There was no general consensus about 1) the ash concentration, 2) the effective threat posed by volcanic ash, 3) the necessity of air space closure and 4) how to be better prepared in the case of a similar future scenario.

Our experiments demonstrate a significant difference in material properties between volcanic ash from Eyjafjallajökull volcano (EYJA) and the two mineral sands (ATD and MIL). In turbines, the ingested matter is subject to rapid heating. Volcanic ash usually contains a significant fraction of glass whose composition commonly ranges from 40 to 80 wt.\% $\mathrm{SiO}_{2}$. This value should not be misinterpreted as representing quartz. Table 1 shows that MIL is nearly pure quartz, while ATD is mainly comprised of quartz grains coated with secondary phases. These phases break down during heating and release volatiles, leading to a reduction of sample weight (Figure 4). EYJA does not contain any quartz as only ATD and MIL results show a peak at $573+/-2{ }^{\circ} \mathrm{C}$, indicative of the $\alpha-\beta$-transition of the quartz structure (Figure 5).

When heated, glass requires significantly less energy than crystalline matter to change from solid to liquid. Glass does not melt, it softens and transitions to a liquid state. This "glass transition" range was constrained to be between 600 and $800^{\circ} \mathrm{C}$ at a heating rate of $10 \mathrm{~K} / \mathrm{min}$ for EYJA (Figure 6). This result differs strongly from results achieved on experimentally generated samples of the same composition (Mechnich et al. 2011). We postulate that this difference lies in the cooling history of our natural

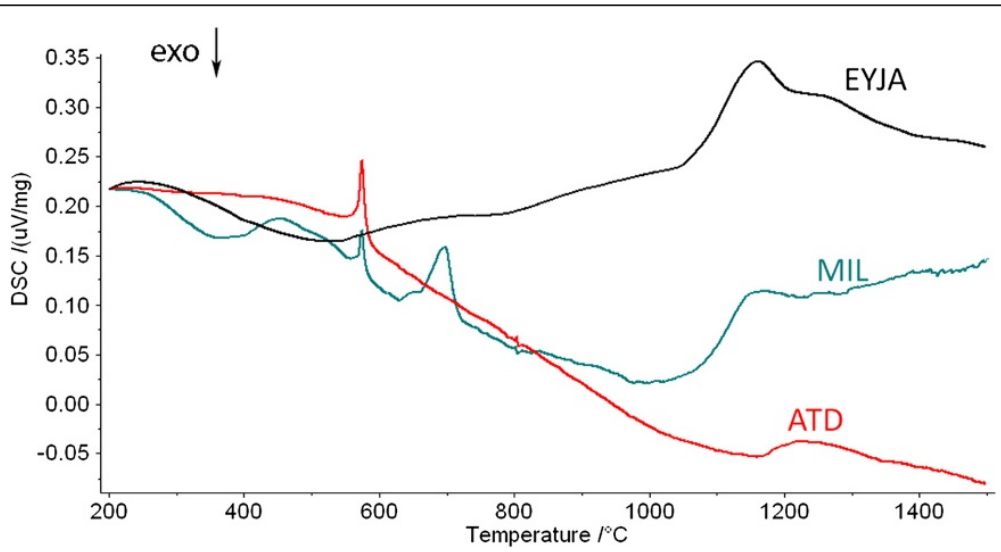

Figure 5 Low-res DSC results (Pt crucibles were used at $10 \mathrm{~K} / \mathrm{min}$ heating rate under argon atmosphere.) for the $90<\varphi<125 \mu \mathrm{m}$ grainsize fraction. Only ATD and MIL show the a- $\beta$-quartz transition at $573^{\circ} \mathrm{C}$. MIL shows further secondary peaks between 400 and $700^{\circ} \mathrm{C}$ manifesting the decomposition of secondary phases. The EYJA sample shows a slight bump between 600 and $750^{\circ} \mathrm{C}$. This bump corresponds to the relaxation of the glass phase upon heating (= glass transition interval) and is shown in a more pronounced way in Figure 6. 


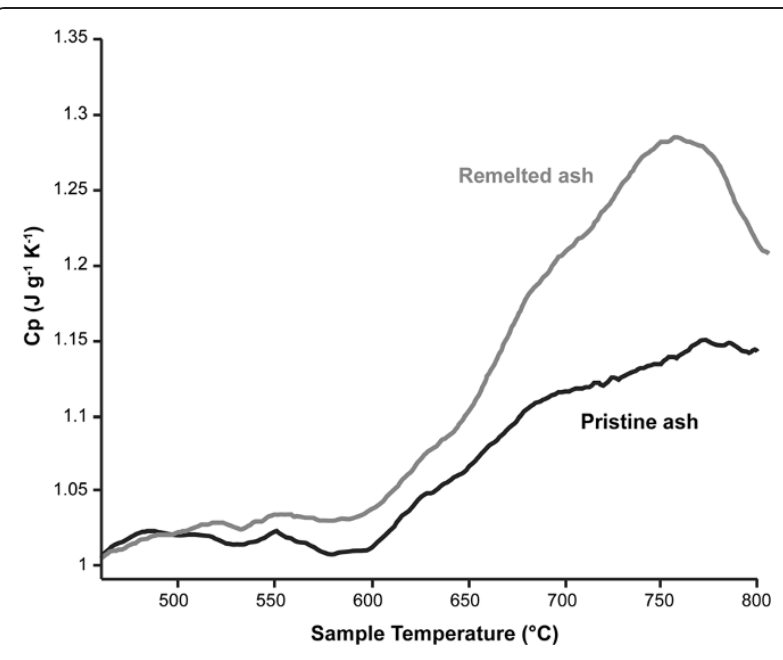

Figure 6 High-resolution DSC results (Platinum crucibles were used at $10 \mathrm{~K} / \mathrm{min}$ heating rate under argon atmosphere.) for the $90<\phi<125 \mu \mathrm{m}$ grainsize fraction of EYJA. The black curve was achieved measuring a pristine sample as collected in the field. The grey curve was achieved measuring a remelted sample after the thermogravimetry experiment (Figure 5). The peak at $750^{\circ} \mathrm{C}$ can be attributed to the glass transition. The peak of the pristine ash is less pronounced due to the crystals content in the ash grains. The curve of "remelted ash" shows the minor difference between bulk rock and interstitial melt.

samples and not in the composition alone. The glass transition peak is less pronounced than for pure glasses; we relate this to the presence of crystals in the glass and a distribution of iron in different oxidation states (Kremers et al. 2012).

As the viscosity of the EJYA samples below $800^{\circ} \mathrm{C}$ is very high, no significant flow was possible on experimental timescales (up to 2 hours) and the onset of macroscopic sintering had only been recognized for experiments at $>850^{\circ} \mathrm{C}$. Figure 3 shows that temperatures of $1000^{\circ} \mathrm{C}$ needed to be achieved in order to allow for significant neck formation (Figure 3b) and $1050^{\circ} \mathrm{C}$ to achieve values of viscosity low enough to allow for considerable viscous flow during the timescale of the experiments (Figure 3c). When ingested in the hot zone of turbines, where significantly higher temperatures can be reached, volcanic ash particles are quickly transformed into liquid droplets that have a high probability of adhering to surfaces. In order to adhere (and not bounce off) at high impact velocities (higher than the travel speed of the airplane), the viscosity of the melt must be low enough. Viscosities are strongly dependent on temperature (turbine operation dependent), $\mathrm{SiO}_{2}$ content (volcano dependent) and the amount of volatiles still dissolved in the melt (pressure dependent). Pressures in the hot zone of turbines can be as high as 300 bar (A. Durant, pers. comm.) and could prevent an outgassing of the melts, thereby keeping the viscosities low (Hess and Dingwell 1996).
Based on our empirical findings from static experiments, we calculated the viscosity of a silicate melt (EYJA interstitial melt composition) as a function of temperature and chemical composition according to Giordano et al. (2008) and constrained $10^{8} \mathrm{~Pa} \mathrm{~s}$ as the critical value of viscosity to achieve sintering in our experiments. This corresponds to $880^{\circ} \mathrm{C}$. For ATD and MIL, 1100 and $1300^{\circ} \mathrm{C}$, respectively, have to be achieved for similar values of viscosity (based on bulk rock composition). We stress that these are most likely minimum temperature values, as higher deformation rates upon impact of moving particles onto surfaces in the turbines will require lower values of viscosity to permit sticking (Wieland et al. 2012). The melting point of pure quartz is around $1700^{\circ} \mathrm{C}$ and is usually not achieved in passenger jet turbines. As a consequence, ingested MIL will not affect the turbines thermally. In multiphase systems, the bulk melting point is lowered to the eutectic temperature. The investigated ATD is comprised by quartz with up to $23 \mathrm{wt} . \%$ of other phases. These phases break down during heating (but before $700^{\circ} \mathrm{C}$ ) and release volatiles. Possible phases are clay minerals (releasing $\mathrm{H}_{2} \mathrm{O}$ ) and/or calcite (releasing $\mathrm{CO}_{2}$ ). As a consequence, melting was observed for ATD at $1200^{\circ} \mathrm{C}$.

Adhering melt droplets will affect the flow of cooling air through the turbine, both as a whole and over individual components. Additionally, the silicate melt may interact chemically (not part of this study) and mechanically with the thermal barrier coating (TBC) on component surfaces in the hot zone of the turbine. At low viscosity, the melt will flow into the intercrystalline pore space of the TBC. Upon cooling, differential contraction due to differences in thermal expansivity of glass and the TBC, may cause damage to the thermal barrier coatings.

We still face difficulties in quantifying the concentrations of volcanic ash in a small volume of air at high temporal and spatial reliability (Sears et al. 2013). Thus, ash ingestion tests should be performed to constrain the effect of ash concentration and total load. We stress that fresh volcanic ash should be used in order to avoid a bias of the results due to alteration/weathering effects. Certainly, ingestion tests with standard sands cannot be reliable proxies for the thermal risk of volcanic ash in turbines. We are convinced that concentration thresholds alone fail to account for the possible impact of ingested volcanic ash on the operational reliability of passenger jet turbines. We propose the introduction of an ash dose threshold as the impact of volcanic ash on the operational reliability of passenger jet turbines is the result of 1 ) ash concentration $\left.\left(\mathrm{mg} / \mathrm{m}^{3}\right), 2\right)$ the amount of air ingested per second (up to hundreds of $\mathrm{m}^{3}$, dependent on flight situation) and 3) the time span an airplane will possibly travel in ash-contaminated air space. 


\section{Appendix}

\section{Electron microprobe analysis}

Groundmass glass and crystal phases were analysed for major elements by electron microprobe on a Cameca SX100 at the University of Munich (LMU), Germany. An accelerating voltage of $15 \mathrm{kV}$, a $15 \mathrm{nA}$ beam current, a defocused $3 \mu \mathrm{m}$ spot size and ZAF correction procedures were used. $\mathrm{Na}$ and $\mathrm{K}$ were analysed first on their respective spectrometers for $10 \mathrm{~s}$ on the peak and $5 \mathrm{~s}$ on the background. Peak and background analysis times for $\mathrm{Si}, \mathrm{Ti}, \mathrm{Al}, \mathrm{Fe}, \mathrm{Mg}$ and $\mathrm{Ca}$ were $20 \mathrm{~s}$ and $10 \mathrm{~s}$, for $\mathrm{Mn}, \mathrm{Ni}$, $\mathrm{Cr}, \mathrm{P} 30 \mathrm{~s}$ and $10 \mathrm{~s}$, for $\mathrm{S} 50 \mathrm{~s}$ and $25 \mathrm{~s}$, while for $\mathrm{Cl}$ they were $240 \mathrm{~s}$ and $120 \mathrm{~s}$, respectively. To check for homogeneity at least 10 analyses were collected on the glass and at least 5 on the crystals.

\section{SEM analysis}

Micro-scale observations of ash particles was performed using a JEOL JSM 6500 F Field Emission (Schottky-type) Scanning Emission Microscope (FE-SEM) at the Instituto Nazionale di Geofisica e Vulcanologia - Roma.

In comparison to conventional SEMs, FE-SEMs offer a more stable electron source and a smaller beam capable of higher spatial resolution at a lower acceleration voltage. The nominal resolution of the used FE-SEM is of 1.5 and $3 \mathrm{~nm}$ at 15 and $1 \mathrm{kV}$ voltage acceleration, respectively. Magnifications up to $100.000 \times$ were used to visualize down to sub-micron size features of the particles.

\section{Competing interests}

The authors declare that they have no competing interests.

\section{Authors' contributions}

UK and CC performed and analysed the sintering experiments, KUH the thermogravimetry and DSC analysis. UK, CC and JT investigated the samples before and after the experiments with EMPA and SEM. KUH and FBW reviewed the sintering literature. UK, CC, KUH and DBD discussed the implications of the results. UK, CC, FBW and JT drafted the manuscript. All authors have read and approved the final manuscript.

\section{Acknowledgements}

We thank Willy Aspinall, Paul Ayris, Adam Durant, Marianne Guffanti and Larry Mastin for vivid discussions and fruitful insights. We thank Soraya Heuss-Aßbichler for the XRF measurements and Hilger Lohringer for sample preparation. DBD wishes to acknowledge the support of a Research Professorship LMUexcellent of the Bundesexzellenzinitiative as well as Advanced Grant "EVOKES" 247076 of the ERC. The AXA Research Fund Project "Risk from volcanic ash in the Earth system" has primarily supported this work. We thank the two anonymous reviewers for their input.

\section{Author details}

${ }^{1}$ Earth \& Environmental Sciences, Ludwig-Maximilians-Universität München, Theresienstr. 41, 80333 Munich, Germany. ${ }^{2}$ Istituto Nazionale di Geofisica e Vulcanologia, Via di Vigna Murata 605, 00143 Roma, Italy.

Received: 20 June 2013 Accepted: 10 February 2014 Published: 27 Mar 2014

\section{References}

Bonadonna C, Genco R, Gouhier M, Pistolesi M, Cioni R, Alfano F, Hoskuldsson A, Ripepe M (2011) Tephra sedimentation during the 2010 Eyjafjallajökull eruption (Iceland) from deposit, radar, and satellite observations. J Geophys Res 116:B12202, doi:10.1029/2011JB008462

Budd L, Griggs S, Howarth D, Ison S (2011) A fiasco of volcanic proportions? Eyjafjallajökull and the closure of european airspace. Mobilities 6(1):31-40

Casadevall TJ (1994) Volcanic ash and Aviation Safety; Proceedings of the First International Symposium on Volcanic Ash and Aviation Safety Held in Seattle. U.S. Geological Survey Bulletin, Washington, p 2047, in July 1991

Dellino P, Gudmundsson MT, Larsen G, Mele D, Stevenson JA, Thordarson T, Zimanowski B (2012) Ash from the Eyjafjallajökull eruption (Iceland): Fragmentation processes and aerodynamic behaviour. J Geophys Res 117: B00C04, doi:10.1029/2011JB008726

Dunn MG (2012) Operation of gas turbine engines in an environment contaminated with volcanic ash. J Turbomach 134(5):051001-051001-18, doi: 10.1115/1.4006236

Dunn MG, Wade DP (1994) Influence of volcanic ash clouds on gas turbine engines. In casadevall TJ volcanic ash and aviation safety; proceedings of the first international symposium on volcanic Ash and aviation safety held in Seattle, Washington, in July 1991: U.S. Geol Surv Bull 2047:107-117

Emmott P (2010) Eyjafjallajökull - the impact of volcanic ash on aircraft engines. Oral commun Atlantic Conf Eyjafjallajökull Aviation Keflavik, http://en.keilir. net/static/files/Aviation/PDF/Eyjafjallajokull_and_Aviation_Conference_ Program.pdf

Frenkel J (1945) Viscous flow of crystalline bodies under the action of surface tension. J Phys 9(5):385-391

Gabbard CB, LeLevier RE, Parry JFW (1982) Dust-Cloud Effects on Aircraft Engines Emerging Issues and new Damage Mechanisms. A Case Study of a Mt. St. Helens Experience and its Implications for Nuclear-Weapon-Lofted Dust-Cloud Effects. US Defense Nuclear Agency Report DNA-TR-82-18, http://www.dtra.mil/ documents/foia/DNA-TR-82-18.pdf

Giordano D, Russell JK, Dingwell DB (2008) Viscosity of magmatic liquids: a model. Earth Plan Sci Lett 271:123-134

Gislason SR, Hassenkam T, Nedel S, Bovet N, Eiriksdottir ES, Alfredsson HA, Hem CP, Balogh Zl, Dideriksen K, Oskarsson N, Sigfusson B, Larsen G, Stipp SLS (2011) Characterization of eyjafjallajökull volcanic ash particles and a protocol for rapid risk assessment. Proc Nat Acad Sci 108(18):7307-7312

Gudmundsson MT, Thordarson T, Höskuldsson A, Larsen G, Björnsson H, Prata FJ, Oddsson B, Magnússon E, Högnadóttir T, Petersen GN, Hayward CL, Stevenson JA, Jónsdóttir I (2012) Ash generation and distribution from the april-may 2010 eruption of eyjafjallajökull. Iceland Sci Rep 2:572, 10.1038/ srep00572

Guffanti M, Casadevall TJ, Budding K (2010) Encounters of Aircraft with Volcanic ash Clouds; A Compilation of Known Incidents, 1953-2009. U.S. Geological Survey Data Series 545, http://pubs.usgs.gov/ds/545/DS545.pdf

Hess KU, Dingwell DB (1996) Viscosities of hydrous leucogranitic melts: a nonarrhenian model. Am Min 81:1297-1300

International Civil Aviation Organization [ICAO] (2007) Manual on Volcanic ash, Radioactive Material and Toxic Chemical Clouds, 2nd edn. International Civil Aviation Organization Doc 9691-AN/954, http://uww.paris.icao.int/news/pdf/9691.pdf

International Civil Aviation Organization [ICAO] (2013) IAWWOPSG/7-WP/17, International Airways Volcano Watch Operations GROUP, $7^{\text {th }}$ Meeting, Follow-up of IVATF Recommendation 4/10m - Definitions of visible ash and discernable ash for operational use., accessed May 22, 2013, www.icao.int/ safety/meteorology/iavwopsg/IAWWOPSG\%20Meetings\%20Metadata/ IAWOPSG.7.WP.017.5.pdf

Keller J, Klaudius J, Kervyn M, Ernst GGJ, Mattson HB (2010) Fundamental changes in the activity of the natrocarbonatite volcano Oldoinyo Lengai, Tanzania. Bull Volcanol 72:893-912

Kennedy LA, Russell JK (2012) Cataclastic production of volcanic ash at Mount Saint Helens. Phys Chem Earth 45-46:40-49

Kremers S, Lavallee Y, Hanson J, Hess KU, Chevrel MO, Wassermann J, Dingwell DB (2012) Shallow magma-mingling-driven Strombolian eruptions at Mt. Yasur Volcano, Vanuatu. Geophys Res Lett 39, L21304

Mechnich P, Braue W, Schulz U (2011) High-temperature corrosion of EB-PVD yttria partially stabilized zirconia thermal barrier coatings with an artificial volcanic Ash overlay. J Am Cer Soc 94:925-931

Miller TP, Casadevall TJ (2000) Volcanic ash Hazards to Aviation. In: Sigurdsson H (ed) Encyclopedia of Volcanoes. Academic, San Diego, pp 915-930

Prata AJ, Tupper A (2009) Aviation hazards from volcanoes: the state of the science. Nat Haz 186:91-107

Scherer GW (1977) Sintering of low-density glasses: I, theory. J Am Cer Soc 60(5-6):236-239 
Scherer GW, Bachman DL (1977) Sintering of low-density glasses: II, experimental study. J Am Cer Soc 60(5-6):239-243

Schumann U, Weinzierl B, Reitebuch O, Schlager H, Minikin A, Forster C, Baumann R, Sailer T, Graf K, Mannstein H, Voigt C, Rahm S, Simmet R, Scheibe M, Lichtenstern M, Stock P, Ru ba H, Schäuble D, Tafferner A, Rautenhaus M, Gerz T, Ziereis H, Krautstrunk M, Mallaun C, Gayet JF, Lieke K, Kandler K, Ebert M, Weinbruch S, Stohl A, et al. (2011) Airborne observations of the Eyjafjalla volcano ash cloud over Europe during air space closure in April and May 2010. Atmos Chem Phys 11:2245-2279, http//dx.doi.org/10.5194/acp-11-2245-2011

Sears TM, Thomas GE, Carboni E, Smith AJA, Grainger RG (2013) $\mathrm{SO}_{2}$ as a possible proxy for volcanic ash in aviation hazard avoidance. J Geophys Res (Atmospheres) 118(11), doi:10.1002/jgrd.50505

Song W, Tang L, Zhu X, Wu Y, Rong Y, Zhu Z, Koyama S (2009) Fusibility and flow properties of coal ash and slag. Fuel 88(2):297-304

Sparks RSJ, Tait SR, Yanev Y (1999) Dense welding caused by volatile resorption. J Geol Soc 156(2):217-225

Taddeucci J, Scarlato P, Montanaro C, Cimarelli C, Del Bello E, Freda C, Andronico D, Gudmudsson MT, Dingwell DB (2011) Aggregation-dominated ash settling from the eyjafjallajökull volcanic cloud illuminated by field and laboratory high-speed imaging. Geol 39:891-894

Tomeczek J, Palugniok H, Ochman J (2004) Modelling of deposits formation on heating tubes in pulverized coal boilers. Fuel 83(2):213-221

Uhlmann D, Klein L, Hopper R (1975) Sintering, crystallization, and breccia formation. Moon 13(1-3):277-284

Vasseur J, Wadsworth FB, Lavallee Y, Hess KU, Dingwell DB (2013) Viscous sintering: timescales of viscous densification and strength recovery. Geophys Res Lett 40:5658-5664

Weinzierl B, Sauer D, Minikin A, Reitebuch O, Dahlkötter F, Mayer B, Emde C Tegen I, Gasteiger J, Petzold A, Veira A, Kueppers U, Schumann U (2012) On the visibility of airborne volcanic ash and mineral dust from the pilot's perspective in flight. Phys Chem Earth A 45-46:87-102

Wiegner M, Gasteiger J, Gross S, Schnell F, Freudenthaler V, Forkel R (2012) Characterization of the Eyjafjallajökull ash-plume: Potential of lidar remote sensing. Phys Chem Earth 45-46:79-86

Wieland C, Kreutzkam B, Balan G, Spliethoff H (2012) Evaluation, comparison and validation of deposition criteria for numerical simulation of slagging. Appl Ener 93:184-192

Zarzycki J (1991) Glasses and amorphous solids (Vol 9). In: Cahn RW, Hassen P, Kramer EJ (eds) Materials Science and Technology: a comprehensive treatment. Wiley, VCH Verlagsgesellschaft, Weinheim

10.1186/2191-5040-3-4

Cite this article as: Kueppers et al.: The thermal stability of

Eyjafjallajökull ash versus turbine ingestion test sands. Journal of Applied Volcanology 2014, 3:4

\section{Submit your manuscript to a SpringerOpen ${ }^{\circ}$ journal and benefit from:}

- Convenient online submission

- Rigorous peer review

- Immediate publication on acceptance

- Open access: articles freely available online

- High visibility within the field

- Retaining the copyright to your article

Submit your next manuscript at $\gg$ springeropen.com 